\title{
A new colorful species of Geophagus (Teleostei: Cichlidae), endemic to the rio Aripuanã in the Amazon basin of Brazil
}

\author{
Gabriel C. Deprá1, Sven O. Kullander ${ }^{2}$, Carla S. Pavanelli ${ }^{1,3}$ and Weferson J. da Graça ${ }^{4}$
}

Geophagus mirabilis, new species, is endemic to the rio Aripuanã drainage upstream from Dardanelos/Andorinhas falls. The new species is distinguished from all other species of the genus by the presence of one to five large black spots arranged longitudinally along the middle of the flank, in addition to the black midlateral spot that is characteristic of species in the genus and by a pattern of iridescent spots and lines on the head in living specimens. It is further distinguished from all congeneric species, except G. camopiensis and G. crocatus, by the presence of seven (vs. eight or more) scale rows in the circumpeduncular series below the lateral line (7 in G. crocatus; 7-9 in G. camopiensis). Including the new species, five cichlids and 11 fish species in total are known only from the upper rio Aripuanã, and 15 fish species in total are known only from the rio Aripuanã drainage.

Geophagus mirabilis, espécie nova, é endêmica da drenagem do rio Aripuanã, a montante das quedas de Dardanelos/ Andorinhas. A espécie nova se distingue de todas as outras espécies do gênero pela presença de uma a cinco manchas pretas grandes distribuídas longitudinalmente ao longo do meio do flanco, em adição à mancha preta no meio do flanco característica das espécies do gênero, e por um padrão de pontos e linhas iridescentes sobre a cabeça em espécimes vivos. Além disso, se distingue de todas as espécies congêneres, exceto G. camopiensis e G. crocatus, pela presença de sete (vs. oito ou mais) séries de escamas na série circumpeduncular abaixo da linha lateral (7 em G. crocatus; 7-9 em G. camopiensis). Com a espécie nova existem cinco ciclídeos, e ao todo 11 espécies de peixe conhecidas somente do alto rio Aripuanã, e ao todo 15 espécies de peixe conhecidas apenas da bacia do rio Aripuanã.

Key words: Geophagini, Geophaginae, Endemism, Taxonomy, Neotropical Region.

\section{Introduction}

The South American cichlid genus Geophagus Heckel is distinguished by the presence of prolongations of the swim bladder into the caudal region that reach past the vertical through the base of the last anal-fin ray, accompanied by a series of supporting caudal ribs (Kullander, 1998). The genus comprises 19 valid species distributed throughout the Amazon and Orinoco river basins, coastal rivers of the Guianas, and some coastal basins in the Brazilian states of Pará, Maranhão, and Piauí (Kullander, 2003; Stawikowski \& Werner, 2004).

Kullander (1995: 158) reported an undescribed species of Geophagus from the rio Aripuanã drainage upstream from Dardanelos/Andorinhas falls. The rio Aripuanã is a major right bank tributary of the lower rio Madeira, and the Dardanelos falls mark its entry into the Madeira floodplain. Although it has been little explored, many works recorded species of fishes in the upper rio Aripuanã (e.g., Kullander, 1990, 1995; Rocha et al., 2008a, 2008b), and the fish fauna is distinct from that from the rio Madeira proper and the floodplain portion of the rio Aripuanã, as reported by Rapp Py-Daniel et al. (2007). The Geophagus from the rio Aripuanã was exported for the ornamental fish market in 2011 and has been cultivated in aquaria in Europe and North America (Gottwald, 2011). Specimens available to Kullander (1995) had been collected as early as 1975 and were not well preserved, thereby delaying the species'

${ }^{1}$ Universidade Estadual de Maringá, Programa de Pós-Graduação em Ecologia de Ambientes Aquáticos Continentais (PEA). Av. Colombo, 5790, 87020-900 Maringá, PR, Brazil. gabrieldepra@gmail.com

${ }^{2}$ Department of Vertebrate Zoology, Swedish Museum of Natural History, P.O. Box 50007, SE-104 05 Stockholm, Sweden. sven. kullander@nrm.se

${ }^{3}$ Universidade Estadual de Maringá, Núcleo de Pesquisas em Limnologia, Ictiologia e Aquicultura (Nupélia). Av. Colombo, 5790, 87020-900 Maringá, PR, Brazil. carlasp@nupelia.uem.br

${ }^{4}$ Universidade Estadual de Maringá, Departamento de Biologia, Núcleo de Pesquisas em Limnologia, Ictiologia e Aquicultura (Nupélia), Programa de Pós-Graduação em Biologia Comparada (PGB). Av. Colombo, 5790, 87020-900 Maringá, PR, Brazil. weferson@nupelia. uem.br 
description. However, recent material collected in 2004, 2005 and 2013, including live color images, permitted a formal description of the species, which is provided herein.

\section{Material and Methods}

Measurements were taken with digital calipers to the nearest $0.1 \mathrm{~mm}$. Counts of scales, fin rays and gill rakers were made under a stereomicroscope. Measurement procedures and counts follow Kullander (1986) and Kullander \& Nijssen (1989). Meristic data marked by an asterisk are the values for the holotype. Numbers in parenthesis after a count value represent the frequency of occurrence in the sample. Osteological characters were examined in one specimen (NUP 15117, $85.5 \mathrm{~mm} \mathrm{SL}$ ) cleared and stained (c\&s) using the protocol by Taylor \& Van Dyke (1985), supplemented by vertebral counts from nine $X$-radiographed specimens (INPA 1364). Measurements of the lower pharyngeal jaw follow Barel et al. (1977). The term midlateral spot is used herein according to nomenclature established in early papers (e.g., López-Fernández \& Taphorn, 2004), meaning a black marking situated approximately on the middle of the flank and present in all species of Geophagus, with the exception of individuals of $G$. altifrons Heckel, which has been observed first by Heckel (1840) in its original description.

Meristic data of Geophagus altifrons, G. camopiensis Pellegrin and $G$. megasema Heckel were obtained exclusively from comparative specimens examined, since their original descriptions follow other methodologies, incompatible with the one adopted herein (e.g. Heckel, 1840; Pellegrin, 1903). From other species examined and from those species that are not listed under 'Material examined', values provided by original descriptions (Kullander \& Nijssen, 1989; Kullander, 1991; Kullander et al., 1992; López-Fernández \& Taphorn, 2004; Schindler \& Staeck, 2006; Staeck \& Schindler, 2006; Lucinda et al., 2010; Hauser \& López-Fernández, 2013) or recent redescriptions (Kullander, 1986; Kullander \& Nijssen, 1989) were also included, since they were obtained from a different and much wider set of specimens, better representing the actual variability of each species.

Institutional abbreviations are: CPUFMT, Coleção de Peixes da Universidade Federal de Mato Grosso, Cuiabá, Brazil; INPA, Instituto Nacional de Pesquisas da Amazônia, Manaus, Brazil; MCP, Museu de Ciências e Tecnologia, Pontifícia Universidade Católica do Rio Grande do Sul, Porto Alegre, Brazil; MZUSP, Museu de Zoologia da Universidade de São Paulo, São Paulo, Brazil; NMW, Naturhistorisches Museum, Wien, Austria; NRM, Swedish Museum of Natural History, Stockholm, Sweden; NUP, Coleção Ictiológica do Núcleo de Pesquisas em Limnologia, Ictiologia e Aquicultura, Maringá, Brazil; and UFRO-I, Coleção Ictiológica da Universidade Federal de Rondônia, Porto Velho, Brazil.

\section{Results \\ Geophagus mirabilis, new species \\ Figs. 1, 2, 5}

Holotype. MCP 48123, $124.1 \mathrm{~mm}$ SL, Brazil, State of Mato Grosso, município de Aripuanã, rio Madeira basin, rio Aripuanã, $2 \mathrm{~km}$ upstream from Dardanelos/Andorinhas falls, approximately $10^{\circ} 10^{\prime} 08^{\prime \prime} \mathrm{S} 59^{\circ} 28^{\prime} 00^{\prime \prime} \mathrm{W}$, elevation 120 m, 22 Oct 2005, F. Machado.

Paratypes. All from Brazil, State of Mato Grosso, all from the município of Aripuanã, except when otherwise mentioned, rio Madeira basin, rio Aripuanã drainage upstream from Dardanelos/Andorinhas falls. CPUFMT 1886, 2, 100.8$108.8 \mathrm{~mm}$ SL, collected with the holotype. INPA 1364 , 10, 64.1-118.3 mm SL, rio Aripuanã, 26 Sep 1975, F. M. Carvalho. INPA 1385, 13, 32.6-89.5 mm SL (1, $89.5 \mathrm{~mm}$ SL), rio Aripuanã, $10^{\circ} 10^{\prime} 00^{\prime}$ 'S 59²7’34”'W, 8 Nov 1976, Ichthyology Team of INPA. INPA 39685, 1, $98.5 \mathrm{~mm} \mathrm{SL}$, igarapé Genipapo, tributary to rio Aripuanã $70 \mathrm{~km}$ from the falls, Ichthyology Team of INPA. MZUSP 101064, 2, 64.0$67.0 \mathrm{~mm}$ SL, rio Aripuanã, immediately upstream from the falls, $10^{\circ} 12^{\prime} 33^{\prime \prime S} 59^{\circ} 27^{\prime} 39^{\prime \prime} \mathrm{W}, 6$ Apr 2004, C. M. C. Leite, F. Rosa \& N. E. Silva. MZUSP 101074, 8, 65.9-84.1 mm SL (3, 65.9-84.1 mm SL), immediately upstream from the falls, $10^{\circ} 12^{\prime} 33^{\prime \prime}$ S 59 27'39”W, 13 Oct 2004, C. M. C. Leite, F. Rosa \& N. E. Silva. MZUSP 114761, 3, 75.3-118.7 mm SL, immediately upstream from the falls, 6 Apr 2005. MZUSP $114762,25,19.3-43.9 \mathrm{~mm}$ SL, immediately upstream from the falls, 6 Apr 2004, F. Machado. F. Machado. NUP 15117, 6 (1 c\&s, 85.5 mm SL), 19.0-107.8 mm SL (4, 85.5-107.8 mm SL), município de Juína, rio Azul, tributary to rio Aripuanã, elevation $280 \mathrm{~m}, 1^{\circ} 02^{\prime} 11.37^{\prime \prime S} 59^{\circ} 11^{\prime} 05.18^{\prime \prime} \mathrm{W}, 15 \mathrm{Jan}$ 2013, H. Pains da Silva \& C. H. Zawadzki. UFRO-I 21151, 5, 136.0-162.1 mm SL (1, $162.1 \mathrm{~mm} \mathrm{SL})$, rio Aripuanã, $10^{\circ} 12^{\prime} 49^{\prime}$ 'S $59^{\circ} 27^{\prime} 26^{\prime}$ 'W, 21 Jul 2013, D. Hungria. UFRO-I 21284, 2, 93.1 and $101.8 \mathrm{~mm} \mathrm{SL}$, road between Aripuanã and Juína, 10³9’33”S 59॰20’13”W, 21 Jul 2013, W. M. Ohara. UFRO-I 21285, 2, 151.6 and $173.8 \mathrm{~mm}$ SL, rio Aripuanã, $10^{\circ} 12^{\prime} 49^{\prime \prime S} 59^{\circ} 27^{\prime} 26^{\prime}$ 'W, 21 Jul 2013, W. M. Ohara.

Non-type material. MZUSP 114760, 32, 8.3-23.8 mm SL. Brazil. State of Mato Grosso, rio Aripuanã immediately upstream from Dardanelos falls.

Diagnosis. Geophagus mirabilis differs from all other species in Geophagus by the presence of 2-6 black spots in a longitudinal row along middle of flank (Fig. 1) in specimens larger than $80 \mathrm{~mm}$ SL ( $v s$. a single midlateral spot or spots absent from flank in individuals of $G$. altifrons), but spots other than midlateral spot absent in occasional specimens up to approximately $80 \mathrm{~mm} \mathrm{SL}$; live coloration of adults with a rich pattern of iridescent blue, round or vermiculate marks on the side of head, unique for the genus (Figs. 2, 5); $4 \frac{1}{2}-5 \frac{1}{2}$ scales between first dorsal-fin spine and upper 
lateral line (vs. 61/2-71/2 in all other species in Geophagus); caudal fin of adults with only one series of scales on each inter-radial membrane of ventral lobe, not imbricating with neighboring series and not completely covering base of rays ( $v s$. two series of scales on each inter-radial membrane of ventral lobe, imbricating both with one another and with neighboring rows and completely covering base of rays, in all other species in Geophagus). It is distinguished from all other species in Geophagus except G. camopiensis and G. crocatus Hauser \& López-Fernández by having 7 circumpeduncular scale rows below lateral line (vs. 8-11); it is distinguished from G. camopiensis by having a narrower lower lip fold, not covering any of dentary lateralis foramina (Fig. 3.A) (vs. broader lower lip fold, covering at least dentary lateralis foramen 1 , in some specimens also dentary lateralis foramen 2; Fig. 3.B), by having light horizontal stripes on the posterior half of caudal fin ( $v s$. only light dots) and by the inter-radial scales series on caudal fin not imbricated ( $v s$. imbricated); it is distinguished from $G$. crocatus by the absence of preopercular mark (vs. presence). Additional characters useful for diagnosis from subsets of Geophagus species include a dark stripe across the cheek absent at all sizes (vs. present in $G$. argyrostictus Kullander, G. gottwaldi Schindler \& Staeck, G. grammepareius Kullander \& Taphorn, G. harreri Gosse, and G. taeniopareius Kullander \& Royero); absence of a dark spot at the corner of the preopercle (preopercular mark) (vs. presence in G. brachybranchus Kullander \& Nijssen, G. crocatus, G. dicrozoster López-Fernández \& Taphorn, G. proximus (Castelnau) and G. winemilleri López-Fernández \& Taphorn); skin fold covering external gill filaments along first ceratobranchial narrow in comparison with filaments (cf. Kullander \& Nijssen, 1989: figs. 20, 27, and 30) (vs. wide in G. brachybranchus, G. harreri and G. surinamensis (Bloch)); E1 scales 29-31 (vs. 33-35 in G. abalios López-Fernández \& Taphorn, 3336 in G. altifrons, 32-34 in G. argyrostictus, 32-33 in G. brachybranchus, 32-34 in G. brokopondo Kullander \& Nijssen, 34-38 in G. dicrozoster, 34-36 in G. gottwaldi, 32-34 in G. megasema, 32-34 in G. proximus, 32-34 in G. surinamensis, 33-35 in G. sveni Lucinda, Lucena \& Assis and 32-35 in G. winemilleri).

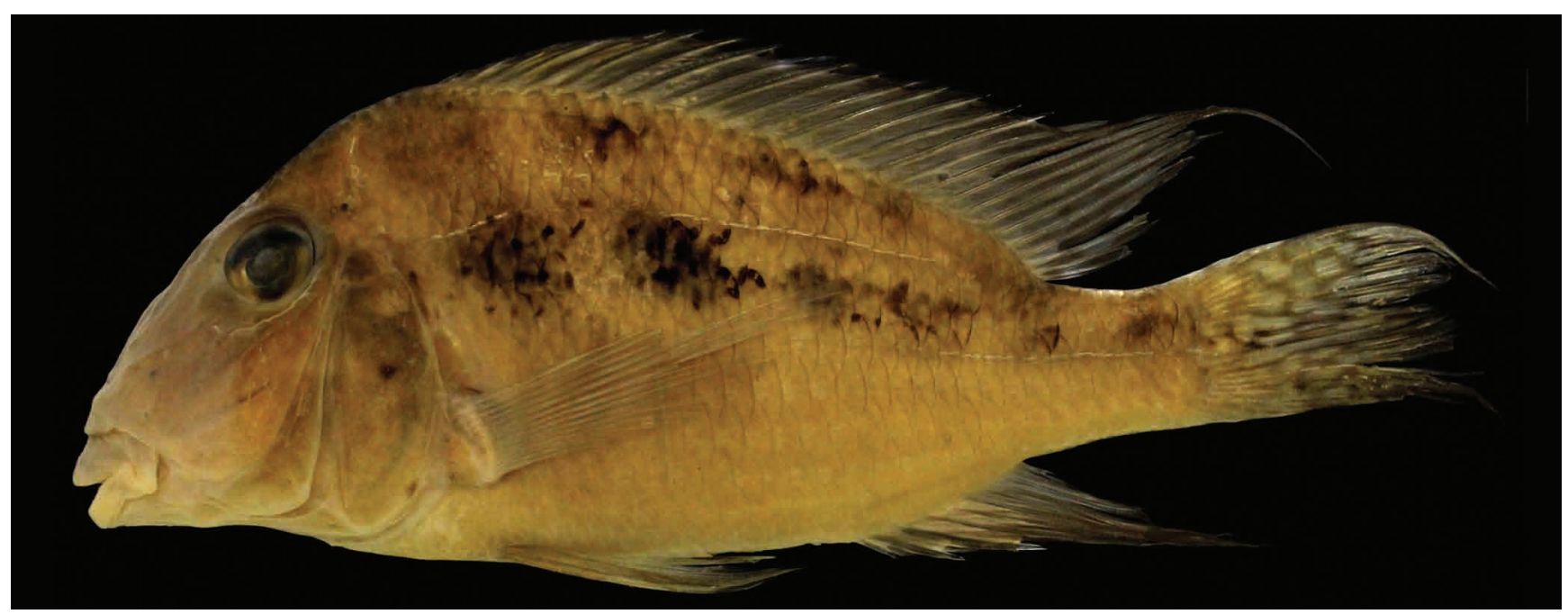

Fig. 1. Geophagus mirabilis, holotype, MCP 48123, $124.1 \mathrm{~mm}$ SL, Brazil, State of Mato Grosso, município de Aripuanã, rio Aripuanã upstream from Dardanelos falls. Photograph by Luiz F. C. Tencatt.

Description. Morphometric data presented in Table 1. Head approximately as deep as long. Mouth terminal, low, slightly dorsal to ventral outline of trunk. Orbit high on head, dorsal to trunk axial midline, its center slightly posterior to midpoint of head length. Dorsalmost point of body at insertion of first dorsal-fin spine; ventralmost point at insertion of pelvic-fin spine. Caudal peduncle shallow, slightly longer than deep. Dorsal head profile (between anterior tip of nasal bone and tip of supraoccipital crest) slightly convex, markedly ascending. Nape profile convex, slightly ascending. Anterior end of dorsal-fin base at same vertical as anterior margin of supracleithrum. Dorsal-fin base profile slightly convex, markedly descending, posteriorly ending at level of horizontal line through middle of eye. Dorsal profile of caudal peduncle concave, slightly descending. Ventral profile of head (between dentary symphysis and ventral tip of cleithrum) nearly straight, slightly descending. Prepelvic profile(along basipterygium) convex, descending. Abdominal profile (between basipterygium and first anal-fin spine) nearly straight, horizontal. Anal-fin base profile convex, ascending. Ventral caudal peduncle profile slightly concave, ascending. Pectoral-fin base oblique, anterior rays posterior to vertical through posterior margin of supracleithrum. Insertion of pelvic-fin spine between verticals through anteriormost and posteriormost pectoral-fin rays. First anal-fin spine insertion at same vertical as insertion of last dorsal-fin spine; last analfin soft ray inserted anterior to vertical through insertion of last dorsal-fin ray. 


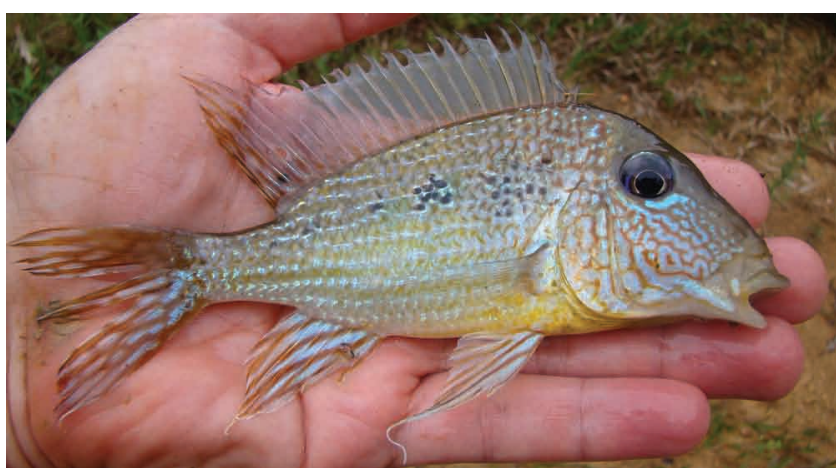

Fig. 2. Geophagus mirabilis, paratype, NUP 15117, 107.8 mm SL, Brazil, State of Mato Grosso, município de Juína, rio Aripuanã, upstream from Dardanelos/Andorinhas falls, immediately after capture. Photograph by Cláudio $\mathrm{H}$. Zawadzki.

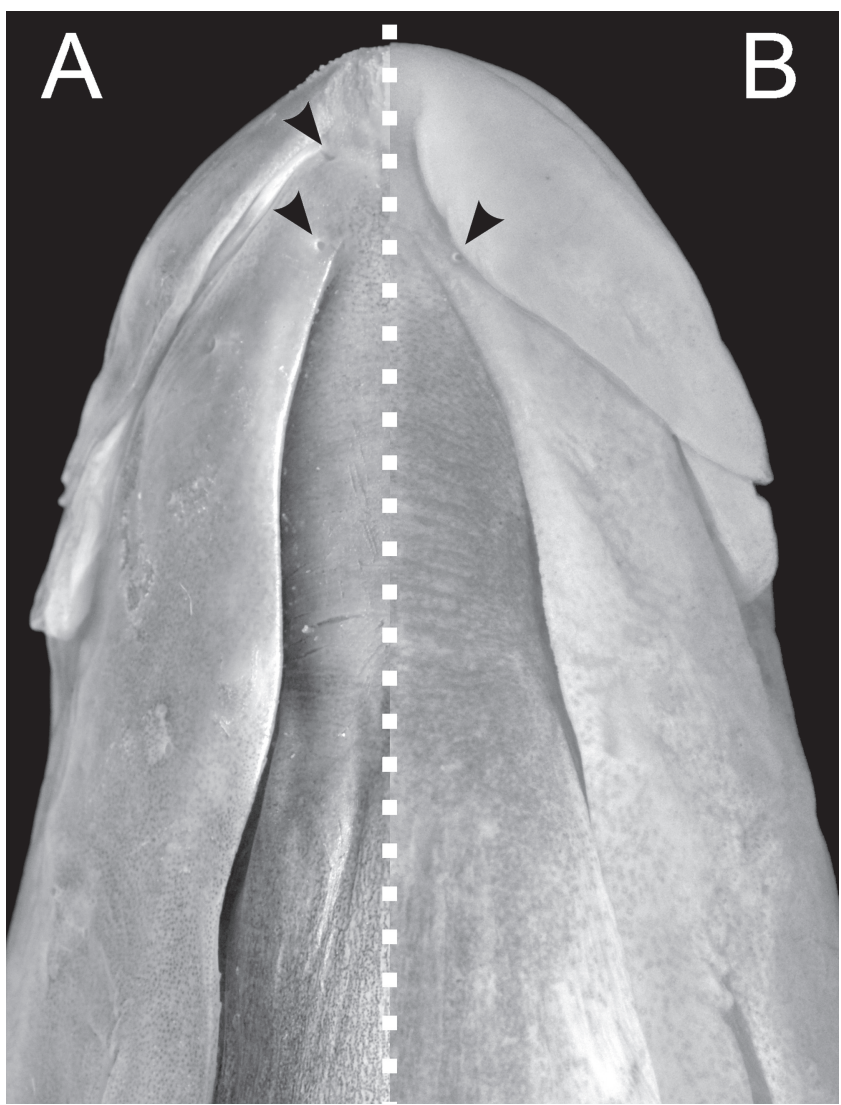

Fig. 3. Ventral view of head, showing the shape of lips, in (A) Geophagus mirabilis, paratype, UFRO-I 21285, $151.6 \mathrm{~mm}$ SL, Brazil, State of Mato Grosso, município de Aripuanã, rio Aripuanã, upstream from Dardanelos/Andorinhas falls; (B) G. camopiensis, MZUSP 32888, 112.6 mm SL. Arrow heads indicate lateralis foramina 1 and 2 in (A) and lateralis foramen 2 in (B). Photograph by Celso Ikedo.

In cross-section, head and trunk laterally compressed. Cross-section of trunk nearly oval, broader ventrally (except caudal peduncle, broader medially). Greatest width between pectoral fin insertions, distance between pelvic-fin spine insertions little narrower. Head flat ventrally, rounded dorsally between snout and interorbital region. In cross-section, nape and dorsal-fin base pointed, strongly compressed; prepelvic region flat ventrally; belly and anal-fin base rounded ventrally; caudal peduncle slightly rounded dorsally and ventrally.

Upper jaw slightly projecting anteriorly to lower jaw or just overlapping it with mouth closed. Nostril slightly anterior to tip of maxillary bone, slightly ventral to horizontal line through lower margin of orbit. Orbit dorsalmost point medial to orbit ventralmost point. Interorbital and internostril areas convex, equally wide, narrower than mouth. Skin covering protruding portion of premaxillary and maxillary bones with many transversal striae. Fleshy lips of "American type", covering dentigerous parts of premaxillary and dentary. Upper lip fold continuous, broader towards lateral ends of premaxillary bones, touching lachrymal and nasal skin when mouth closed. Lower lip fold evenly narrow, interrupted at dentary symphysis, not covering any of dentary lateralis foramina (Fig. 3.A). Lip folds united on tip of maxilla. Thin skin fold on antero-dorsal margin of orbit. Skin fold behind basipterygium bearing large-sized interpelvic scale.

Table 1. Morphometric data for holotype and 19 paratypes of Geophagus mirabilis, new species. SD = standard deviation.

\begin{tabular}{|c|c|c|c|c|}
\hline & Holotype & Paratypes & Mean & $\mathrm{SD}$ \\
\hline Standard length (mm) & 124.1 & $65.9-162.1$ & 105.3 & - \\
\hline \multicolumn{5}{|c|}{ Percents of standard length } \\
\hline Head depth & 35.5 & $32.8-39.6$ & 35.5 & 1.8 \\
\hline Body depth & 41.2 & $41.8-43.0$ & 40.8 & 1.4 \\
\hline Caudal peduncle depth & 12.7 & $11.6-13.4$ & 12.4 & 0.4 \\
\hline Head length & 37.1 & $33.4-38.3$ & 36.1 & 1.3 \\
\hline Pectoral fin length & 35.6 & $31.2-39.1$ & 36.5 & 1.8 \\
\hline Pelvic fin length & 26.5 & $26.9-48.9$ & 36.0 & 7.1 \\
\hline Caudal peduncle length & 16.8 & $16.4-21.3$ & 18.4 & 1.4 \\
\hline Last anal spine length & 14.4 & $12.9-18.5$ & 15.1 & 1.5 \\
\hline Last dorsal spine length & 17.6 & $15.1-19.8$ & 17.7 & 1.4 \\
\hline Predorsal distance & 47.9 & $40.8-46.3$ & 44.0 & 1.8 \\
\hline Prepectoral distance & 38.4 & $35.0-40.0$ & 37.4 & 1.4 \\
\hline Prepelvic distance & 39.2 & $38.2-42.1$ & 39.9 & 1.2 \\
\hline Head width & 14.7 & $13.9-16.0$ & 14.6 & 0.5 \\
\hline Cheek depth & 13.6 & $11.2-14.2$ & 12.6 & 0.8 \\
\hline Lachrymal depth & 14.7 & $11.1-15.0$ & 13.0 & 1.1 \\
\hline Postorbital length & 13.5 & $10.5-13.3$ & 12.3 & 0.7 \\
\hline Upper jaw length & 11.6 & $11.2-13.1$ & 11.8 & 0.5 \\
\hline Lower jaw length & 13.0 & $11.6-14.9$ & 13.4 & 0.8 \\
\hline Snout length & 24.3 & $17.0-23.4$ & 20.9 & 1.7 \\
\hline Orbital diameter & 9.1 & $7.5-11.7$ & 9.6 & 1.1 \\
\hline Interorbital distance & 9.2 & $7.3-9.4$ & 8.4 & 0.6 \\
\hline
\end{tabular}


E1 scales 29(3), 30*(14), 31(9); scales between upper lateral line and dorsal fin $4 \frac{1}{2}(18), 5 \frac{1}{2} *(9)$ anteriorly, $1 \frac{1}{2} 2^{*}(24)$, $2 \frac{1}{2}(3)$ posteriorly. Series of scales between those comprising lateral lines $2 *(27)$; series of scales between last superior lateral line scale and inferior lateral line, $1^{*}(20), 2(7)$; series of scales between lower lateral line and first anal-fin spine, $4(1)$ or 5(5). Scales on upper lateral line $19^{*}(6), 20(5), 21(8)$, 22(6), 23(2) and on lower lateral line 11+1(1), 12+2(8), 12+3(1), $13+1(4), 13+2(6), 13+13(2), 14+1(1), 14+2 *(3), 14+3(1)$. Anterior half of cheek naked, posterior half with cycloid scales, arranged in four to six more or less regular rows. Opercle naked centrally in all but one specimen, but always with ctenoid scales along borders. Subopercle covered with two or three series of cycloid scales, except for thin naked area on postero-ventral margin and naked antero-dorsal process. Interopercle naked or with scales deeply embedded in skin. Single postorbital vertical series of cycloid scales. Supra-cleithrum with two or three large scales, sometimes ventral portion naked. Occipital and flank scales ctenoid. Circumpeduncular scale rows 5(1), $6^{*}(22), 7(4)$ above, $7 *(27)$ below lower lateral line, ctenoid. Scales anterior to pelvic fin minute, much smaller than scales between anus and pelvic fin and much smaller than flank scales. Scales between pelvic spines 5, none extremely enlarged. Scales between medial rays of pelvic fins 1-3, large. Predorsal scales stochastically arranged, almost same size as flank scales.

Pelvic fin naked, except for base of rays, covered by just one scale. Pectoral fin usually completely naked, rarely with few scales on rays near base. Dorsal fin with scale rows on inter-radial membranes, usually between median spines and median soft rays (in one large specimen, from membrane posterior to third spine almost to last inter-radial membrane); scale rows obliquely oriented, not parallel to rays; usually one, up to three scale rows per membrane, separated by naked space; up to six scales per row; scaly pad absent at base of dorsal fin. Anal fin naked in all except two specimens (scales between all soft rays, only one row per membrane, up to two scales per row). Caudal fin covered with scales stochastically distributed from base of rays to one-fifth of their length; from this point, scales ordered in non-imbricated series, one per inter-radial membrane (including membranes between branches of some rays); median series with about five scales, outer series with much more scales (reaching approximately 30 in series comprising lower lateral line branch), leaving middle of fin (between D3 and V3) basically naked and dorsal and ventral parts covered almost until posterior margin; dorsal lateral line branch between rays D3 and D4; ventral branch between rays V4 and V5, longer than dorsal branch.

Dorsal-fin rays $\mathrm{XV}, 10(1), \mathrm{XV}, 11(1), \mathrm{XV}, 12(1), \mathrm{XVI}, 10(3)$, XVI,11*(17), XVI,12(1), XVII,9(1), XVII,10(2). Anal-fin rays III,7(12), III, $8^{*}(15)$. All dorsal- and anal-fin spines slightly curved, middle part thickest, with groove along almost entire posterior margin. All dorsal-fin spines similarly thick; length doubling from $1^{\text {st }}$ to $3^{\text {rd }}$, increasing slightly until $7^{\text {th }}$, then equal until last spine. Dorsal-fin lappets pointed, about one-sixth spine length, also in soft rays. Dorsal fin pointed in region comprised by median soft rays, sometimes forming filament; posteriormost soft rays abruptly shorter. Thickness of anal-fin spines increasing markedly from $1^{\text {st }}$ to $3^{\text {rd }}$ (latter much thicker than dorsal spines); first anal-fin spine length less than half-length of $2^{\text {nd }} ; 3^{\text {rd }}$ spine length less than double $2^{\text {nd }}$ spine length. Middle rays of anal fin pointed with filamentous extension only in very large specimens. Posterior margin of caudal fin slightly concave, with filamentous extensions only in very large specimens. Total pectoral-fin rays $14(6), 15^{*}(8), 16(12)$; fourth ray longest. Pelvic-fin first soft ray longest, external branch longer than internal, with filamentous extension reaching up to anal-fin base in some large specimens. Caudal-fin rays i,7,7,i in one paratype examined.

External gill rakers on first gill arch: $6+10(1), 7+12(3)$, $8+11(2), \quad 8+12(7), \quad 9+10(1), 9+11(2), 9+12(4), 9+13(2)$, $10+12(3)$. Width of skin fold over gill filaments (from border to closest gill raker) half length of exposed part of external gill filaments on middle of ceratobranchial; equal to length of exposed part of external gill filaments on ceratobranchial extremities.

Premaxillary teeth more or less arranged in four or five series close to symphysis. Teeth of outer series 15(1), 18(1), 20(1), 22(1), 23(2), 24(1), 25(1) on each side, about twice as large as those from subsequent series, wide space between them. All premaxillary teeth inwards inclined. Dentary teeth not arranged in series, more numerous near symphysis. Outer teeth 17(1), 21(2), 22(1), 24(2), larger than inner teeth especially near symphysis.

Ceratobranchial 4 with six tooth-plates, each with two (rarely one) rows of slender unicuspid teeth. Ceratobranchials 5 with slight interdigitation ventrally; postero-medial teeth large, cylindrical, with large, blunt, dorsally oriented cusp and $0-2$ very small, blunt, anteriorly oriented cusps; anterolaterally, teeth gradually diminishing in size; outer teeth very compressed transversally, with large, sharp, antrorse cusp and 0-2 very small, blunt, antrorse cusps (Fig. 4). Tooth-plate length including postero-lateral processes $107 \%$ of width; length of dentigerous area $66 \%$ of width; ten teeth along symphyseal margin, 26 along outer margin.

Pharyngobranchial 2 with thick ventral portion, bearing about six rows of slender teeth, up to two retrorse cusps each. Pharyngobranchial 3 with nine rows of teeth (medialmost row with large, cylindrical teeth with up to four cusps; laterally, teeth progressively compressed, decreasing in size; lateralmost teeth with up to three cusps). Pharyngobranchial 4 teeth small, continuing dentition pattern of pharyngobranchial 3, about eight rows.

One supraneural, anterior to first neural spine. Abdominal ribs 13 pleural, first on third vertebra, last two decreasing in length; 11 epineural, first on first vertebra. Caudal ribs continuing pleural series, 8-10; caudal ribs bifurcate dorsally but not ventrally (observed in c\&s specimen, not visible in X-radiographs); strongly decreasing in size until last rib, which is not more than a small nodule. 
All caudal vertebrae attached to caudal prolongations of swim bladder (one on each side, observed in c\&s specimen). Vertebrae 14+16(1), 14+17(5), 15+15(4); long hypapophyses fused ventrally, restricted to third abdominal vertebra; anteriormost caudal vertebra with hemal spine plus pair of basapophyses; two posteriormost abdominal vertebrae with basapophyses contacting medially; five posteriormost centra totally included in caudal peduncle; seventh and eighth posteriormost vertebrae with an anterior expansion on hemal spine apparently for articulation with last ribs.

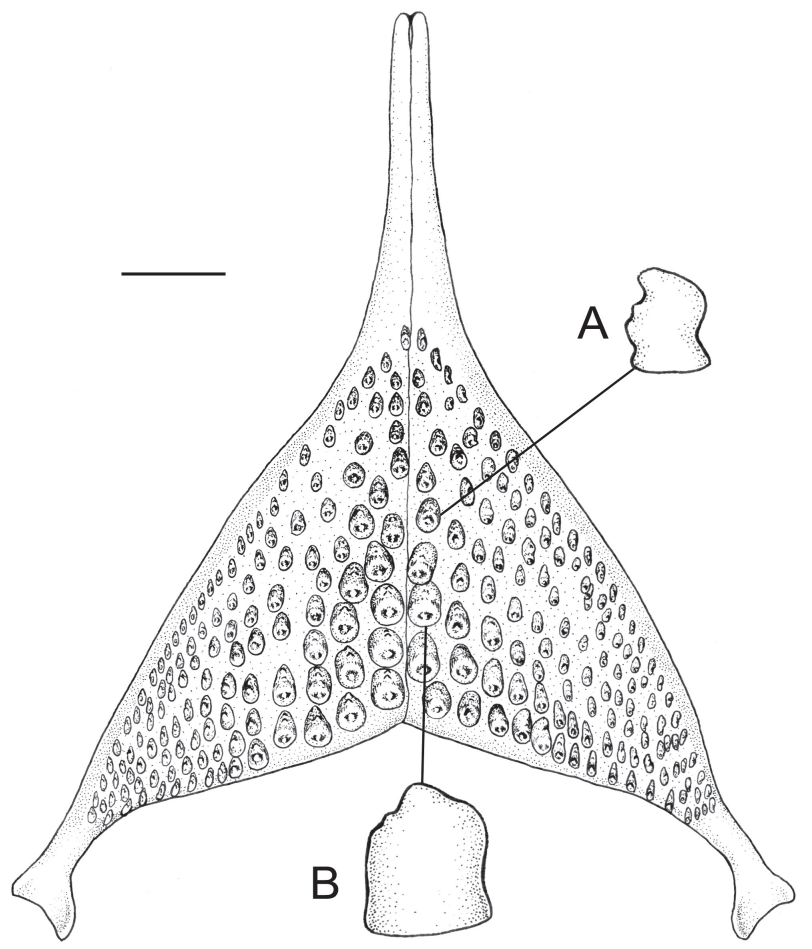

Fig. 4. Geophagus mirabilis, NUP 15117, $107.8 \mathrm{~mm}$ SL, Brazil, State of Mato Grosso, município de Juína, rio Aripuanã, upstream from Dardanelos/Andorinhas falls. Lower pharyngeal jaw in occlusal aspect, anterior portion upwards. (A) and (B), lateral view of two different teeth, proportionally enlarged, anterior portion to left side. Scale bar $=1 \mathrm{~mm}$, not applied to (A) and (B).

Color in alcohol. Background color yellowish pale brown, darker over lachrymal, nasal, premaxilla (including upper lip), frontal bones and nape; lighter over dentary and angulo-articular bones and in region between ventral edge of cleithrum and posterior margin of basipterygium (Fig. 1). Throat dark. Few specimens with a few dark marks on sides of head, corresponding to iridescent blue marks of live specimens. Flanks little darker dorsally than ventrally, with six grayish-brown vertical bars from dorsal-fin base to E0 scale row, fading two rows below. Dorsal end of each bar in relation to dorsal-fin rays as follows: first, between nape and first spine; second, between fifth and tenth spines; third, between $11^{\text {th }}$ and $16^{\text {th }}$ spines; fourth, between third and seventh soft rays; fifth, around last soft ray; sixth, slightly behind midpoint of caudal peduncle. Some individuals without visible bars, most with only bars 1, 2, and 3 visible. Bars inclined, their dorsal ends more anterior than ventral ends. Melanophores forming vertical bars located underneath scales, imbedded in dermis. An amorphous black spot on each bar, coinciding with E1 and E2 scale rows; spot on second bar corresponding to midlateral spot, always present; spots on bars 1, 3, 4, 5, and 6 absent in some individuals. Melanophores forming all spots located both in dermis and epidermis; dermal melanophores equally spread within round area; epidermal melanophores forming several clusters (Figs. 1-2) in larger individuals, equally spread within round area in smaller ones. Pectoral fin hyaline. Dorsal, caudal, anal, and pelvic fins with pale gray, somewhat brownish ground color. Dorsal fin with oval, unpigmented spots over inter-radial membranes of last four or five soft rays, their long axis parallel to radial axis. In some individuals, similar marks can be observed among all soft rays, seemingly forming two very faint stripes parallel to dorsal profile of body. Caudal fin ground color a little darker than dorsal fin, particularly in middle inter-radial membrane. Proximal portion of caudal fin with spots of same color, shape and orientation as in dorsal fin, but distally spots gradually fuse, appearing as longitudinal parallel stripes over distalmost third. Anal and pelvic fins with even darker ground color, with faint light, unpigmented stripes (about four or five). Anal-fin stripes almost horizontal, slightly descending posteriorly, axis not corresponding to radial axis, contrasting with pelvic-fin stripes. Very large specimens with faint vertical bars on flank, black spots with clusters of melanophores more scattered, darker head and throat. Young with black spots rounded, not scattered, and caudal fin sometimes without longitudinal light stripes. Very young individuals with light dots forming vertical bars on caudal fin.

Color in life. Eyes brownish gray, with light yellow ring around pupil. Head dorsally brownish gray from upper lip until between eyes. Side of head brownish orange, covered by bluish iridescent vermiculations and spots, sometimes rings, all over opercle, subopercle, preopercle, cheek and lachrymal. Some vermiculations united into stripes along infraorbitals, preopercle, angulo-articular and margin between opercle and subopercle. Lower lip, lower jaw and skin over interopercle pale gray. Intermandibular region and ventral portion of branchiostegal membrane gray to dark gray. Flank ground pale gray dorsally, becoming white ventrally. Center of each scale with bluish iridescent spot, seemingly forming a longitudinal stripe along each scale row. Margin of each scale orange, seemingly forming zigzag longitudinal stripes between scale rows. Black spots of flank scattered, permeated by bluish iridescent spots. Prepelvic area and area between pelvic and pectoral fins covered by scattered yellow to orange spots. Pectoral fin hyaline. Other fins with same ground color as head, light (unpigmented) marks observed in alcohol-preserved specimens appearing as bluish-iridescent. 
Spinous portion of dorsal fin translucent, gray. Young with only a few faint vermiculations on side of head, prepelvic region white and anal fin uniformly orange (Figs. 2, 5).
Distribution. Geophagus mirabilis is known from the rio Aripuanã drainage, upstream from Dardanelos/Andorinhas falls (Fig. 6).

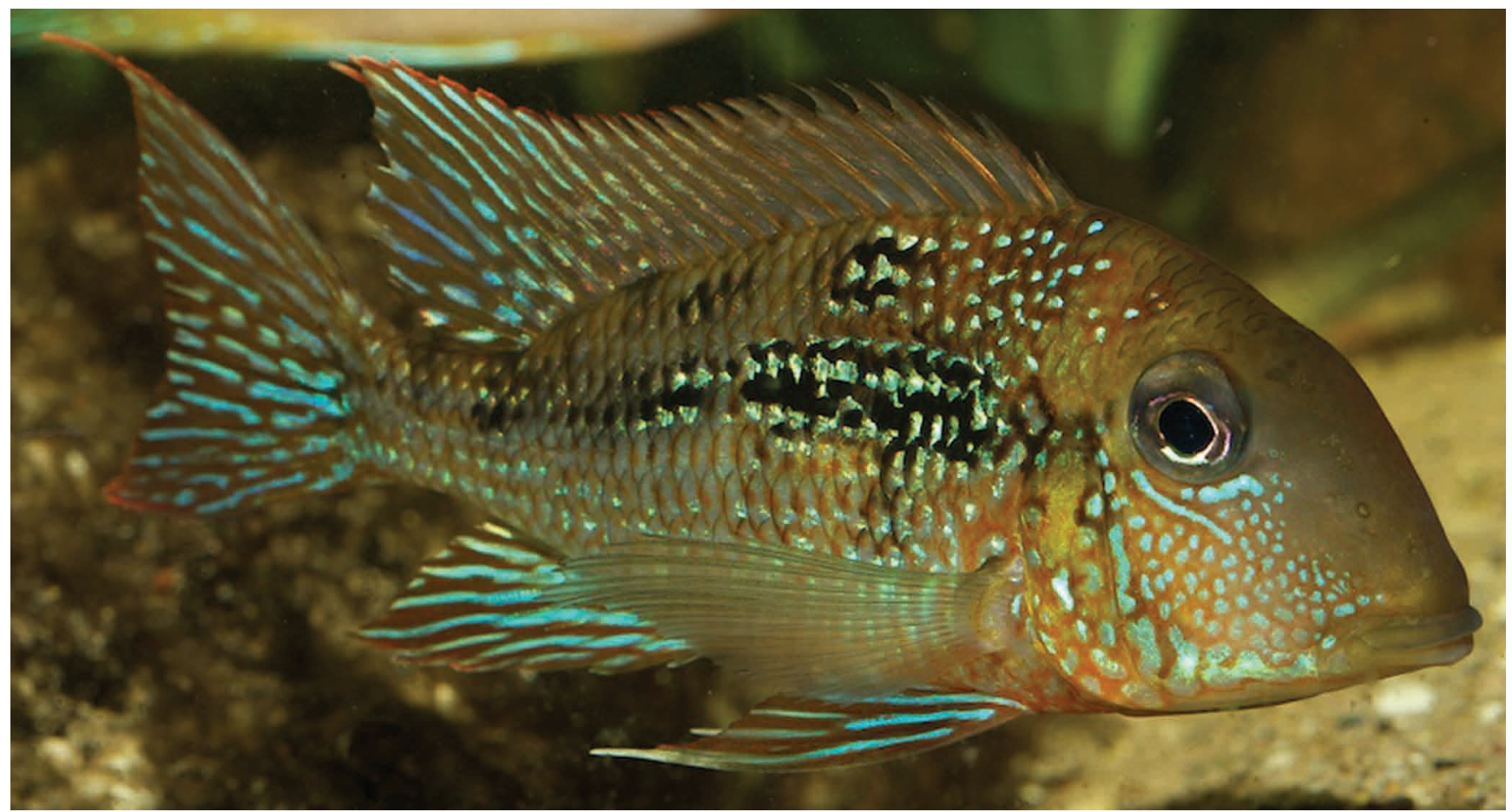

Fig. 5. Geophagus mirabilis, living specimen in aquarium, not preserved. Photograph by Oliver Lucanus.

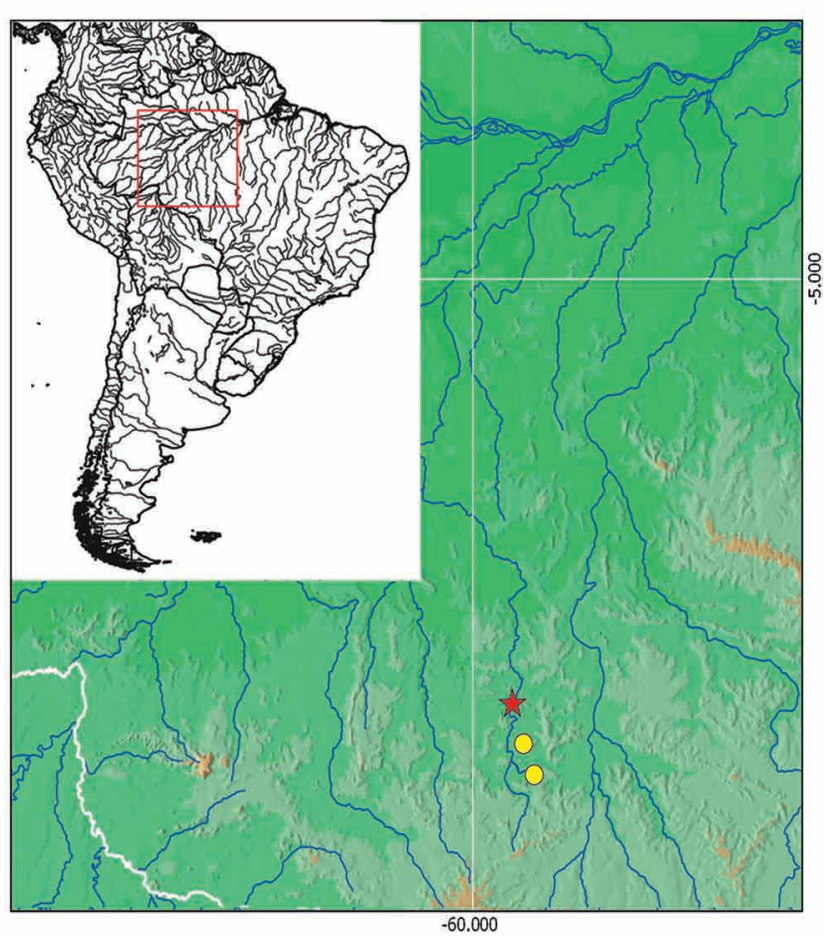

Fig. 6. Map of the geographic distribution of Geophagus mirabilis. Star corresponds to type-locality; circles correspond to other localities where the species is found. One symbol can correspond to more than one locality.
Etymology. Named in reference to the unique color pattern that includes the row of black spots on the flanks and the iridescent spots and vermiculations on the side of the head in living individuals; the Latin adjective mirabilis means extraordinary, marvelous, admirable.

Remarks. Specimens from MZUSP 114760 were excluded from the type series because of the very small size and bad preservation, but likely represent Geophagus mirabilis.

\section{Discussion}

Traditionally, Geophagus was a catch-all genus for large cichlids with an expanded anteroventral lamina on the first epibranchial, lined with gill-rakers as originally diagnosed by Heckel (1840) and in the revision by Regan (1906). In the most recent revision of the genus, Gosse (1976) recognized the three genera Geophagus, Biotodoma Eigenmann \& Kennedy and Gymnogeophagus MirandaRibeiro. Kullander (1983; 1986) revalidated Satanoperca Günther and referred Geophagus steindachneri Eigenmann \& Hildebrand and Geophagus brasiliensis (Quoy \& Gaimard) to new, still formally unnamed genera. At the time, the resultant Geophagus sensu stricto contained only the three species considered valid by Gosse (1976), viz. G. camopiensis, G. harreri, and G. surinamensis. Recent taxonomic revisions have resulted in revalidations 
of the synonyms and new species for a total of 19 species (Kullander, 1986; Kullander \& Nijssen, 1989; Kullander, 1991; Kullander et al., 1992; López-Fernandez \& Taphorn, 2004; Schindler \& Staeck, 2006; Staeck \& Schindler, 2006; Lucinda et al., 2010; Hauser \& López-Fernández, 2013).

Monophyly of Geophagus is well established by morphological (Kullander, 1998) and molecular (LópezFernández et al., 2005) analyses. Geophagus is unique among cichlids because it has long posterior swim bladder diverticles supported by short ribs continuing the pleural series as far as the $9^{\text {th }}$ to $16^{\text {th }}$ hemapophysis (Kullander, 1998). Species taxonomy so far has been based on the color pattern, particularly the suborbital mark, the size and position of the midlateral spot, the number of vertical bars on the side, and the color pattern on the caudal fin, as well as the width of the exposed portion of the gill blade (Kullander, 1986; Kullander \& Nijssen, 1989; LópezFernández \& Taphorn, 2004).

All species in Geophagus present a large dark brown or black spot on the middle of the side, the midlateral spot. In addition to subtle differences in size and among the species, the only significant variation known until now was the ontogenetic variation of that spot in G. altifrons, in which it becomes progressively smaller with increasing body size and may be absent in large specimens. The midlateral spot is also present in G. mirabilis, but in this species, it is one of a series of spots along the side. This coloration pattern resembles that of South American cichlids in general, in which there are usually a midlateral spot and/or a row of spots and a dark horizontal band along the middle of the side. Among geophagine cichlids, the coloration pattern of G. mirabilis is very similar to that of other species in the rio Madeira drainage, viz. Satanoperca pappaterra (Heckel), which has a series of blackish spots along the middle of the side and along the dorsum (Heckel, 1840). This color pattern is unique within Satanoperca. Satanoperca pappaterra has so far been found only in the rio Guaporé basin, in Brazil and Bolivia, and in the upper rio Paraguay basin, in Brazil and Paraguay. Its geographical range is thus completely separated from that of $G$. mirabilis. The color pattern in life of G. mirabilis also shows a very unusual character in Geophagus. The presence of light bluish reflecting spots and vermiculations on the side of the head resembles the pattern present in many South American cichlids, including some species of Satanoperca (Stawikowski \& Werner, 2004), but has not been recorded in any other species in Geophagus.

In species of Geophagus the caudal ribs are normally simple, without bifurcation in both extremities, as in $G$. altifrons, G. brachybranchus, G. grammepareius, G. cf. sveni (NUP 15803) and G. taeniopareus. In the c\&s $G$. mirabilis, however, the caudal ribs are split proximally, and in G. neambi Lucinda, Lucena \& Assis (NUP 9039), they are split distally.

Geophagus mirabilis has relatively large scales, $4 \frac{1}{2}-5^{1 / 2}$ between superior lateral line and first dorsal-fin spine and
29-31 in the E1 row, which is unusual among Geophagus species, which always have $61 / 2$ or more scale series above the lateral line and usually more than $31 \mathrm{E} 1$ scales, and more similar to the counts recorded for species of Satanoperca, as in Kullander \& Ferreira (1988). Low numbers of E1 scales overlapping with $G$. mirabilis are found in $G$. grammepareius (30-31; río Orinoco basin), G. camopiensis (30-32; Oyapock, Approuague, and Amapari river basins), Geophagus parnaibae Staeck \& Schindler (30-31; rios Parnaíba and Mearim basins), G. taeniopareius (31-33; río Orinoco basin), G. harreri (31-34; Marowijne River basin) and Geophagus neambi (30-34; rios Tocantins-Araguaia basin). In their attempt to identify monophyletic groups within Geophagus, Staeck \& Schindler (2006: 74) used low scale counts in combination with a low modal number (7) of anal-fin soft rays to define two "clades" within the "Geophagus surinamensis complex" distinguished by López-Fernández \& Taphorn (2004). One of them would be composed of G. camopiensis and G. parnaibae, which had the lowest counts. This hypothesis was not based on a phylogenetic analysis, however, and no character state was presented to support monophyly of the remaining species in the G. surinamensis "complex". The "Geophagus surinamensis complex" was distinguished by LópezFernández \& Taphorn (2004) for species traditionally identified as G. surinamensis and characterized by a deep body and head, a large midlateral spot and the suborbital stripe in adults either absent or represented by a dark mark at the corner of the preopercle. They contrasted it to more elongate species with a prominent vertical stripe from the eye to the preopercle but did not attempt a phylogenetic analysis. Geophagus mirabilis clearly falls into the former category, but there is no support for relationships with $G$. camopiensis or G. parnaibae. As shown above, there is a gradual variation in scale counts from the lowest in $G$. mirabilis to the maximum of 38 in G. dicrozoster, and no obvious non-arbitrary natural break point.

Geophagus mirabilis is restricted to a long stretch of the rio Aripuanã basin from right above the Dardanelos/ Andorinhas falls to many kilometers upstream, and it is the only species in the genus that occurs upstream from the falls. Kullander (1995) listed 10 fish species (including $G$. mirabilis) known from the upper rio Aripuanã, including the entire upstream stretch and, in some cases, a distance of few kilometers downstream from Dardanelos/Andorinhas falls, as well as its tributaries that drain into those stretches. From that list of species, Lasiancistrus scolymus Nijssen \& Isbrücker (Loricariidae) is now considered a synonym of the widespread L. schomburgkii (Günther) (Armbruster, 2005); and Crenicichla guentheri Ploeg has been synonymized with the local endemic $C$. hemera Kullander (Varella et al., 2012). A species overlooked by Kullander (1995), Utiaritichthys longidorsalis Jégu, Tito de Morais \& Santos (Serrasalmidae), and the recently described Trachycorystes menezesi Britski \& Akama (Auchenipteridae) and Hypostomus dardanelos Zawadzki 
\& Carvalho (Loricariidae) should be added to the list, changing the number of valid species considered endemic to that region to 11, including Geophagus mirabilis (Jégu et al., 1992; Britski \& Akama, 2011; Zawadzki \& Carvalho, 2014). If we consider all of the species thought to be endemic to the rio Aripuanã basin as a whole, the number rises to at least 15 (Rocha et al., 2008a, 2008b; Zanata \& Ohara, 2009; Ribeiro et al., 2011; Eschmeyer, 2014). The fish fauna of the upper rio Aripuanã may be more closely related to that of the adjacent rio Tapajós headwaters. Varella et al. (2012) suggested that the cichlid Crenicichla hemera in the upper rio Aripuanã may be the sister species of the locally endemic $C$. chicha Varella, Kullander \& Lima in the adjacent rio Juruena. Netto-Ferreira et al. (2009) described Jupiaba yasi Netto-Ferreira, Zanata, Birindelli \& Sousa from the rio Teles-Pires drainage and from the rio Aripuanã immediately dowstream of the Dardanelos/Andorinhas falls. Curiously, it has not been reported from the rio Juruena headwaters so far. Specimens of Geophagus from the rios Juruena and Arinos represent a deep-bodied species with a midlateral spot but no further dark spots on the side, nine circumpeduncular scales ventral to the lateral line, and approximately 35 scales in the E1 row. No additional species in Geophagus have been reported from the rio Juruena.

Material examined. Geophagus altifrons. Brazil. Amazonas. MZUSP 7079, 2, 109.2-119.7 mm SL, rio Canumã, rio Madeira basin. MZUSP 57948, 1, $120.1 \mathrm{~mm} \mathrm{SL}$, rio Negro at Manaus. MZUSP 74856, 2, 77.7-85.0 mm SL, rio Cuieiras, rio Negro basin at Manaus. NMW 17007, 1, syntype, rio Negro at Manaus. NMW 17008, 1, syntype, rio Negro at Manaus. Geophagus argyrostictus. Brazil. Pará. Rio Xingu basin. MZUSP 36875, 3, 102.3-140.3 mm SL, rio cachoeira do Espelho, Altamira. Geophagus camopiensis. Brazil. Amapá. Rio Amapari basin. MZUSP 32888, 5, 102.9-130.3 mm SL, rio Cupixi. Geophagus megasema. Brazil. Mato Grosso. Rio Guaporé basin. MZUSP 37503, 3, 156.0-188.4 mm SL, rio Alegre. NMW 16246, 1, syntype. NMW 90309, 1, syntype. Geophagus neambi. Brazil. Tocantins. Rio Araguaia basin. NUP 8257, 1, $83.0 \mathrm{~mm} \mathrm{CP}$, rio Lontra. NUP 8368, 1, $68.0 \mathrm{~mm} \mathrm{SL}$, unnamed creek, tributary to rio Araguaia. NUP 9039, 2, 65.0 and $80.0 \mathrm{~mm}$ SL (1 c\&s, 80.0 $\mathrm{mm}$ SL), rio Araguaia. Geophagus parnaibae. Brazil. Maranhão. MZUSP 43624, 2, 58.1 and $74.7 \mathrm{~mm} \mathrm{SL}$, igarapé do Engenho, rio Pindaré-Mearim basin. MZUSP 87505, 3, 100.4-106.9 mm SL, rio Parnaíba basin. Piauí. Rio Parnaíba basin. MZUSP 74933, 1, 120.0 mm SL, rio Poti. MZUSP 98612, 4, 40.0-110.0 mm SL, Parnaguá, praia dos Crioulinhos. Geophagus proximus. Brazil. Amazonas. NUP 6636, 1, 178.6 mm CP, lago Coari, rio Solimões basin. Geophagus sveni. Brazil. Goiás. NUP 13077, 5, 65.4$126.2 \mathrm{~mm}$ SL, rio Crixás-Açu, rio Araguaia basin. Geophagus winemilleri. Brazil. Amazonas. MZUSP 27239, 1, $142.3 \mathrm{~mm}$ SL, rio Negro basin at Novo Ayrão (in Reserva Ecológica das Anavilhanas). Geophagus sp. Brazil. Mato Grosso. NRM 46911, $145.7 \mathrm{~mm}$ SL, rio Juruena.

\section{Acknowledgments}

We are grateful to Hugmar P. da Silva and Cláudio H. Zawadzki (Nupélia) for showing us the fishes from the collection in which the new species was caught and to Cláudio for sharing with us the picture of the live fish. To Alexandre C. Ribeiro (CPUFMT), for the loan of specimens. To Fernando Carvalho (DZSJRP) for taking many useful pictures from $G$. megasema and $G$. altifrons syntypes housed in NMW. To Michel Gianeti, Oswaldo Oyakawa, and Henrique Varella (MZUSP) for helping us find the specimens in the collection. To Christian Cramer (UFRO) and Rafaela P. Ota (INPA) for searching their collections for specimens of the new species. To Willian Ohara, who also helped us find specimens at UFRO. To Luiz F. C. Tencatt and Celso Ikedo (Nupélia) for taking the pictures of the holotype and paratype, respectively. To Oliver Lucanus for kindly allowing us to use his picture of the fish in the aquarium. To Luiz F. C. Tencatt and Renata R. Ota (Nupélia) for reading the first draft of the manuscript. We thank Nupélia, PEA for logistic support, the Coordenação de Aperfeiçoamento de Pessoal de Nível Superior (CAPES) for the scholarship and Proex/CAPES for travel support. CSP has been supported by grants by the Conselho Nacional de Desenvolvimento Científico e Tecnológico (CNPq) and WJG by the Fundação Araucária (SETI-PR).

\section{Literature Cited}

Armbruster, J. W. 2005. The loricariid catfish genus Lasiancistrus (Siluriformes) with descriptions of two new species. Neotropical Ichthyology, 3: 549-569.

Barel, C. D. N., M. J. P. van Oijen, F. Witte \& E. L. M. Witte-Maas. 1977. An introduction to the taxonomy and morphology of the haplochromine Cichlidae from lake Victoria. Netherland Journal of Zoology, 27: 333-389.

Britski, H. A. \& A. Akama. 2011. New species of Trachycorystes Bleeker, with comments on other species in the genus (Ostariophysi: Siluriformes: Auchenipteridae). Neotropical Ichthyology, 9: 273-279.

Eschmeyer, W. N. (Ed.). 2014. Catalog of Fishes: Genera, Species, References. Electronic version. California Academy of Sciences. San Francisco. Available from: http://research. calacademy.org/research/ichthyology/catalog/fishcatmain. asp. (17 Mar 2014).

Gosse, J. P. 1976. Révision du genre Geophagus (Pisces, Cichlidae). Memoires de l'Académie Royale des Sciences d'Outre-Mer, Classe des Sciences Naturelles et Médicales, 19: 1-172.

Gottwald, J. 2011. Ein aquaristisch neuer Erdfresser aus dem Rio Aripuanã. DATZ, 64: 36-37.

Hauser, F. E. \& H. López-Fernández. 2013. Geophagus crocatus, a new species of geophagine cichlid from the Berbice River, Guyana, South America (Teleostei: Cichlidae). Zootaxa, 3731: 279-286.

Heckel, J. 1840. Johann Natterer's neue Flussfische Brasilien's nach den Beobachtungen und Mittheilungen des Entdeckers (Erste Abtheilung, die Labroiden). Annalen des Wiener Museums der Naturgeschichte, 2: 325-470. 
Jégu, M., L. Tito de Morais \& G. M. dos Santos. 1992. Redescription des types d'Utiaritichthys sennaebragai Miranda Ribeiro, 1937 et description d'une nouvelle espèce $\mathrm{du}$ bassin amazonien, $U$. longidorsalis (Characiformes, Serrasalmidae). Cybium, 16: 105-120.

Kullander. S. O. 1983. Taxonomic studies on the percoid freshwater fish family Cichlidae in South America. Unpublished Ph.D. Dissertation, Stockholm University, Stockholm, 440p.

Kullander, S. O. 1986. Cichlid fishes of the Amazon River drainage of Peru. Stockholm, Swedish Museum of Natural History.

Kullander, S. O. 1990. Crenicichla hemera, a new cichlid species from the Rio Aripuanã drainage, Mato Grosso, Brazil. Ichthyological Exploration of Freshwaters, 1: 213-218.

Kullander, S. O. 1991. Geophagus argyrostictus, a new species of cichlid fish from the rio Xingu, Brazil. Cybium, 15: 129138.

Kullander, S. O. 1995. Three new cichlid species from Southern Amazonia: Aequidens gerciliae, A. epae and A. michaeli. Ichthyological Exploration of Freshwaters, 6: 149-170.

Kullander, S. O. 1998. A phylogeny and classification of South American Cichlidae (Teleostei: Perciformes). Pp. 461-498. In: Malabarba, L. R., R. E. Reis, R. P. Vari, Z. M. S. Lucena \& C. A. S. Lucena (Eds.). Phylogeny and Classification of Neotropical fishes. Porto Alegre, Edipucrs.

Kullander, S. O. 2003. Family Cichlidae (Cichlids). Pp. 605-654. In: Reis, R. E., S. O. Kullander \& C. J. Ferraris, Jr. (Eds.). Check List of the Freshwater Fishes of South and Central America. Porto Alegre, Edipucrs.

Kullander, S. O. \& E. J. G. Ferreira. 1988. A new Satanoperca species (Teleostei, Cichlidae) from the Amazon River basin in Brazil. Cybium, 12: 343-355.

Kullander, S. O. \& H. Nijssen. 1989. The cichlids of Surinam (Teleostei: Labroidei). Leiden, E. J. Brill.

Kullander, S. O., R. Royero \& D. C. Taphorn. 1992. Two new species of Geophagus (Teleostei: Cichlidae) from the río Orinoco drainage in Venezuela. Ichthyological Exploration of Freshwaters, 3: 359-375.

López-Fernández, H. \& D. C. Taphorn. 2004. Geophagus abalios, $G$. dicrozoster and G. winemilleri (Perciformes: Cichlidae), three new species from Venezuela. Zootaxa, 439: 1-27.

López-Fernández, H., R. L. Honeycutt, M. L. Stiassny \& K. O. Winemiller. 2005. Morphology, molecules and character congruence in the phylogeny of South American geophagine cichlids (Perciformes, Labroidei). Zoologica Scripta, 34: 627-651.

Lucinda, P. H. F., C. A. S. Lucena \& N. C. Assis. 2010. Two new species of cichlid fish genus Geophagus Heckel from the rio Tocantins drainage (Perciformes: Cichlidae). Zootaxa, 2429: 29-42.

Netto-Ferreira, A. L., A. M. Zanata, J. L. O. Birindelli \& L. M. Sousa. 2009. Two new species of Jupiaba (Characiformes: Characidae) from the rio Tapajós and rio Madeira drainages, Brazil, with an identification key to the species in the genus. Zootaxa, 2262: 53-68.
Pellegrin, J. 1903. Description de Cichlidés nouveaux de la collection du Muséum. Bulletin du Muséum national d'Histoire naturelle, 9: 120-125.

Rapp Py-Daniel, L., C. P. de Deus, O. M. Ribeiro \& L. M. de Souza. 2007. Peixes. Pp. 90-117. In: Rapp Py-Daniel, L., C. P. de Deus, A. L. Henriques, D. M. Pimpão, O. M. Ribeiro (Eds.). Biodiversidade do Médio Madeira: bases científicas para propostas de conservação. Manaus, INPA; and Brasília, MMA - MCT.

Regan, C. T. 1906. A revision of the South-American cichlid genera Retroculus, Geophagus, Heterogramma, and Biotoecus. Annals and Magazine of Natural History (7), 17: 49-66.

Ribeiro, F. R. V., W. S. Pedroza \& L. H. Rapp Py-Daniel. 2011. A new species of Nemuroglanis (Siluriformes: Heptapteridae) from the rio Guariba, rio Madeira basin, Brazil. Zootaxa, 2799: 41-48.

Rocha, M. S., R. R. de Oliveira \& L. H. Rapp Py-Daniel. 2008a. Scolopax baskini: a new dwarf catfish from rio Aripuanã, Amazonas, Brazil (Loricarioidei: Scoloplacidae). Neotropical Ichthyology, 6: 323-328.

Rocha, M. S., R. R. de Oliveira \& L. H. Rapp Py-Daniel. 2008b. A new species of Gladioglanis Ferraris \& Mago-Leccia from rio Aripuanã, Amazonas, Brazil (Siluriformes: Heptapteridae). Neotropical Ichthyology, 6: 433-438.

Schindler, I. \& W. Staeck. 2006. Geophagus gottwaldi sp. n. - a new species of cichlid fish (Teleostei: Perciformes: Cichlidae) from the drainage of the upper rio Orinoco in Venezuela. Zoologische Abhandlungen, 56: 91-97.

Staeck, W. \& I. Schindler. 2006. Geophagus parnaibae sp. n. - a new species of cichlid fish (Teleostei: Perciformes: Cichlidae) from the rio Parnaíba basin, Brazil. Zoologische Abhandlungen, 55: 69-75.

Stawikowski, R. \& U. Werner. 2004. Die Buntbarsche Amerikas, Band 3: Erdfresser, Hecht- und Kammbuntbarsche. Stuttgart, Ulmer.

Taylor, W. R. \& G. C. van Dyke. 1985. Revised procedures for staining and clearing small fishes and other vertebrates for bone and cartilage study. Cybium 9: 107-119.

Varella, H. R., S. O. Kullander \& F. C. T. Lima. 2012. Crenicichla chicha, a new species of pike cichlid (Teleostei: Cichlidae) from the rio Papagaio, upper rio Tapajós basin, Mato Grosso, Brazil. Neotropical Ichthyology, 10: 233-234.

Zanata, A. M. \& W. M. Ohara. 2009. Jupiaba citrina, a new species from rio Aripuanã, rio Madeira basin, Amazonas and Mato Grosso states, Brazil (Characiformes: Characidae). Neotropical Ichthyology, 7: 513-518.

Zawadzki, C. H. \& P. H. Carvalho. 2014. A new species of the Hypostomus cochliodon group (Siluriformes: Loricariidae) from the rio Aripuanã basin in Brazil. Neotropical Ichthyology, 12: $43-51$
Submitted July 29, 2014

Accepted September 29, 2014 by Paulo Lucinda

Published December 27, 2014 